\title{
PERANCANGAN BLACKBODYCAVITY TEMBAGA UNTUK KALIBRASI TERMOMETER TELINGA
}

\author{
Design Of Copper Blackbody Cavity For Ear Thermometer \\ Calibration
}

\author{
lip Ahmad Rifai, Melati Azizka Fajria, Dwi Larassati, Aditya Achmadi, \\ Hidayat Wiriadinata, Ghufron Zaid \\ Badan Standardisasi Nasional, Gedung 430 Kompleks PUSPIPTEK, Muncul, Tangerang Selatan \\ Email :iip@bsn.go.id
}

\begin{abstract}
Abstrak
Dengan semakin banyaknya penggunaan temometer telinga dan mulai ditinggalkannya termometer merkuri untuk alat ukur kesehatan, maka ketertelusuran nilai pengukuran termometer telinga ke standar internasional menjadi semakin penting dan pengembangan sistem kalibrasi termometer telinga yang lebih baik lagi menjadi sebuah keharusan. Pada tulisan ini dibahas perancangan blackbody cavity dari tembaga sebagai media kalibrasi termometer telinga. Blackbody Cavity tembaga yang dibuat didesain sedemikian rupa sehingga blackbody cavity mempunyai nilai emisivitas yang mendekati nilai ideal 1 untuk mendekati nilai emisivitas radiator planckian ideal. Hasil perhitungan dan simulasi pada keadaan isothermal menunjukkan bahwa emisivitas spektral efektif hingga > 0,999 dan emisivitas gabungan 0,99982 pada dasar cone cavity blackbody.Pada keadaan non-isothermal emisivitas spektral efektif hingga lebih dari 0,999 dan emisivitas gabungan 0,9996 pada dasar cone cavity blackbody dapat dicapai.
\end{abstract}

Katakunci:termometer telinga, emisivitas, blackbody cavity

\begin{abstract}
With the increasing use of ear thermometers and the abandonment of mercury thermometers for health measuring devices, the traceability of ear thermometer measurement values to international standards is becoming increasingly important and the development of better ear thermometer calibration systems has become a necessity. In this paper, the development of copper blackbody cavity as a calibration media for ear thermometers is discussed. The Blackbody Cavity copper is designed in such a way that the blackbody cavity has an emissivity value close to the ideal value of 1 to approximate the ideal Planckian radiator emissivity value. Calculation and simulation results in an isothermal state show that spectral effective emissivity is more than 0.999 and combined emissivity is 0.99982 on the core of cavity blackbodycone.
\end{abstract}

Keywords:ear thermometer, emissivity, blackbody cavity

\section{PENDAHULUAN}

Suhu badan merupakan salah satu kondisi fisiologis yang digunakan oleh petugas medis untuk menentukan kondisi pasien dimonitor setiap hari. Oleh karena itu, suhu badan harus diukur menggunakan termometer klinik yang mempunyai akurasi yang memadai. Salah satu jenis termometer klinik adalah termometer telinga yang termasuk alat elektromedik yang digunakan untuk mengetahui kondisi kesehatan seseorang dengan salah satu parameter melalui pengukuran suhu pada anggota fisik.
Menurut MedlinePlus, suhu badan manusia sehat ideal pada $36,1^{\circ} \mathrm{C} \sim 37,2^{\circ} \mathrm{C}$, jika melebihi nilai suhu tersebut dapat dikatakan orang tersebut perlu mendapatkan penanganan untuk menurunkan suhu badannya agar tidakberakibat lebih fatal terhadap jiwanya.

Termometer telinga adalah salah satu alat elektromedik berupa termometer klinik yang saat ini sudah sangat banyak digunakan di Indonesia, uji kelayakan termometer klinik diatur oleh pemerintah melalui Undang-Undang (UU) No. 36 tahun 2009 tentang kesehatan, UU No. 44 tahun 2009 tentang rumah sakit, untuk dapat 
memenuhi persyaratan-persyaratan tersebut, alat-alat medis harus dikalibrasi atau diuji secara berkala. Permenkes No. 54 Tahun 2015 Tentang Pengujian dan Kalibrasi Alat Kesehatan, mengatur bahwa alat-alat medis yang digunakan untuk keperluan diagnosa, terapi, rehabilitasi dan penelitian medik baik secara langsung maupun tidak langsung dan memiliki parameter penunjukan, keluaran, atau kinerja wajib untuk dikalibrasi atau diuji secara berkala.

Dilain pihak, kebutuhan permintaan kalibrasi alat-alat elektromedik semakin meningkat tiap tahunnya seiring dengan peningkatan jumlah peralatan kesehatan dan kewajiban untuk mengkalibrasi peralatan kesehatan apabila suatu rumah sakit ingin mengajukan akreditasi. BPFK telah mulai memecahkan permasalahan ini dengan membentuk BPFK milik dinas kesehatan provinsi (Prov. Lampung, Jabar, Kalbar, Banten, Sumsel, Jateng dan Yogyakarta). Dalam pembentukan suatu lab kalibrasi alatalat medis, tentunya diperlukan berbagai macam persiapan. Utamanya persiapan tersebut berupa pengadaan alat-alat kalibrasi dan peningkatan SDM yang akan melaksanakan kegiatan kalibrasi.

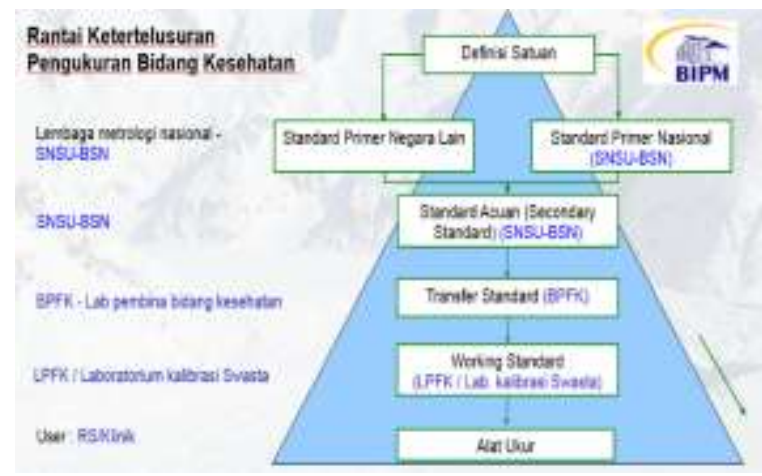

Gambar 1. Skema rantai ketertelusuran pengukuran bidang kesehatan di Indonesia

Sebagai pengelola teknis ilmiah Standar Nasional untuk Satuan Ukuran (SNSU), Badan Standardisasi Nasional (BSN), berkewajiban untuk merealisasikan ketertelusuran pengukuran besaran suhu, termasuk besaran suhu alat elektromedik, yaitu dengan jalan melakukan pemeliharaan standar dan menyediakan fasilitas kalibrasi untuk alat-alat standar suhu. Keterselusuran (traceability) adalah suatu rantai yang tidak terputus dari beberapa perbandingan, yang masing-masing dinyatakan dengan suatu ketidakpastian pengukuran. Hal ini untuk memastikan bahwa suatu hasil pengukuran atau nilai dari suatu standar terpaut dengan suatu acuan yang lebih tinggi, dan seterusnya sampai ke standar primer.

Ketiadaannya ketertelusuran alat ukur kesehatan, terutama alat elektromedik, ke sistem internasional atau SI, dapat berakibat fatal pada interpretasi hasil pengukuran atau pengujian karena tidak ada jaminan kebenaran BSN berupaya menyediakan jaminan ketertelusuran peralatan ukur terutama alat ukur kesehatan yang diakui internasional. Di bidang termometer telinga, langkah tersebut telah dimulai dengan pembuatan beberapa tipe blackbody cavity yang berbeda digabungkan dengan bak cairan besar yang dimiliki BSN sebagai media kalibrasi.

Hasil yang didapat tidak terlalu memuaskan untuk mengejar target nilai maksimum error yang disyaratkan ASTM E 667:98, penelitian lanjutan menemukan bahwa tingkat keseragaman bak cairan yang digunakan turut berpengaruh dalam memberikan sumber ketidakpastian yang besar, hal ini dikarenakan ukuran bak cairannya yang besar yang membuat tingkat keseragamannya tidak cukup bagus sebagai media kalibrasi termometer telinga, sehingga diperlukan pembuatan bak cairan yang memiliki keseragaman yang bagus, salah satu caranya adalah dengan memperkecil ukuran dari bak cairan tersebut. Kelebihan lain dari ukuran kecil bak cairan ini adalah tingkat kepraktisannya yang kedepannya dapat mempermudah pelaksana kalibrasi berkeliling melakukan kalibrasi termometer telinga di fasilitas pelayanan kesehatan, seperti di rumah sakit, puskesmas, dan klinik.

Penelitian sebelumnya telah berhasil membuat blackbody cavity dari alumunium dengan menghasilkan emisivitas spektral efektif pada dasar cone cavity blackbody hingga 0,998 pada keadaan isothermal(Larassati 2015). Pada tulisan ini dibahas pengembangan blackbody cavity dari tembaga sebagai media kalibrasi termometer telinga dengan desain yang dibuat untuk meningkatkan nilai emisivitas, nilai emisivitas efektif dihitung dari simulasi geometri blackbody dan nilai emisivitas gabungan dihitung dari simulasi dengan termometer telinga dengan berbagai macam Field of View (FoV), emisivitas-emisivitas tersebut dihitung dan disimulasikan pada keadaan dinding blacbody isothermal dan non-isothermal dengan perangkat lunak blackbody emissivity versi 1.2. Hasil perhitungan pada keadaan isothermal menunjukkan bahwa emisivitas spektral efektif hingga $>0,999$ dan emisivitas gabungan 0,99982pada dasar conecavityblackbody. Pada keadaan nonisothermalemisivitas spektral efektif hingga $>0,999$ dan emisivitas gabungan 
0,9996pada dasar cone cavity blackbody dapat dicapai.

\section{TINJAUAN PUSTAKA}

Blackbody adalah permukaan ideal/teoritis yang memiliki sifat-sifat tertentu, antara lain perfect absorber yaitu menyerap seluruh radiasi yang jatuh padanya, untuk semua panjang gelombang dan arah datangnya radiasi.

Merata ke semua arah
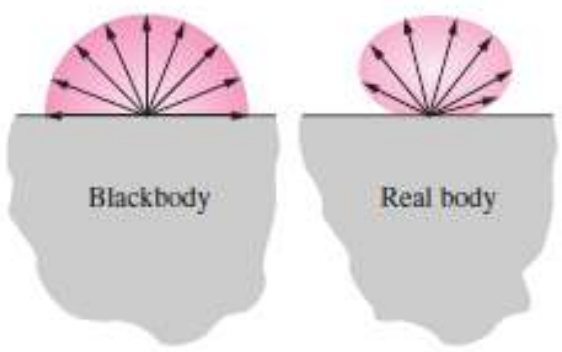

Gambar 2. Besarnya radiasi blackbody tidak bergantung pada arah emisi.

Sifat berikutnya adalah perfect emitter, dimana pada suhu dan panjang gelombang yang sama, blackbody mengemisikan radiasi panas lebih besar daripada benda nyata (realbody). Dan yang terakhir isotropically diffuseemitter dimana radiasi panas yang diemisikan memiliki besar yang sama pada setiap arah pancaran, seperti yang diperlihatkan secara skematis pada Gambar 2. Karena radiasi blackbody tidak bergantung pada arah emisi, maka radiasi spektral ke semua arah besarnya sama sehingga nilainya hanya bergantung pada suhu dan panjang gelombang.Simbol radiasi $\mathrm{L}_{e}\left(\theta, \phi, \lambda_{s} \mathrm{~T}\right)$ diubah menjadi $\mathrm{L}_{\mathrm{b}}\left(\mathrm{O}_{\mathrm{s}} \mathrm{T}\right)$, dengan indeks $\mathrm{b}$ menunjukan blackbody sebagai sumber radiasi panas.

Dengan menggunakan mekanika kuantum, Mac Planck telah merumuskan hubungan antara suhu blackbodydengan radiasi panas yang diemisikannya dalam bentuk Persamaan, seperti yang ditunjukkan pada Persamaan (1):

$$
\mathrm{L}_{\mathrm{b}}(\mathrm{O}, \mathrm{T})=\frac{\mathrm{c}_{1}}{2^{5}\left[\exp \left(\frac{\mathrm{c}_{2}}{2 \mathrm{~T}}\right)-1\right]}
$$

dengan:

$\lambda=$ panjang gelombang radiasi panas, $\mu \mathrm{m}$

$\mathrm{T}=$ suhu blackbody, $\mathrm{K}$

$\mathrm{L}_{\mathrm{b}}(\lambda, \mathrm{T})=$ radiasiblackbody pada panjang gelombang $\lambda$ dan suhu $T, W \cdot m^{-2} \cdot \mu m^{-1} \cdot$ str $^{-1}$
$\mathrm{C}_{1}=$ konstanta Planck pertama $=$

1.19104282.10-16 W. m².

$\mathrm{C}_{2}=$ konstanta Planck kedua $=0,014388 \mathrm{~m} \cdot \mathrm{K}=$ $14388 \mu \mathrm{m} . \mathrm{K}$

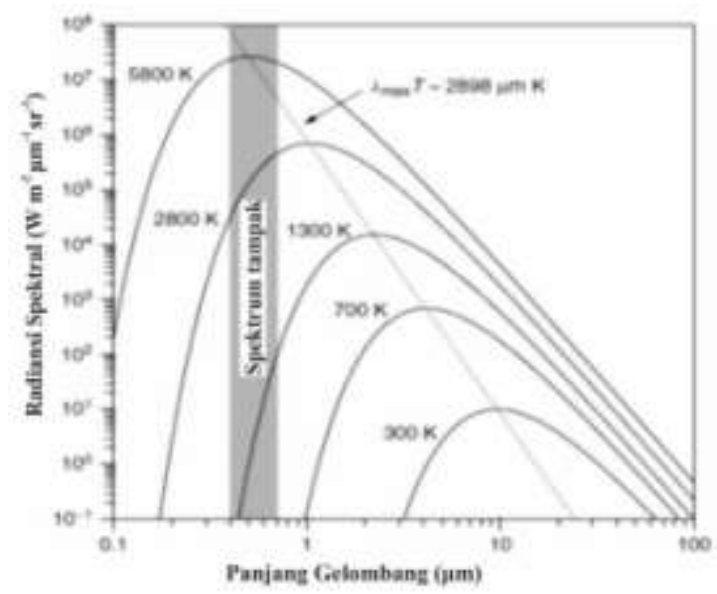

Gambar 3. Grafik radiasiblackbody terhadap panjang gelombang.

Sebagai penyerap sempurna (perfectabsorber) dan emiter sempurna (perfect emitter), blackbody merupakan suatu radiator panas ideal.Tak ada benda lain yang memiliki sifat yang persis sama dengan blackbody. Berdasarkan pada Persamaan (1) untuk suatu nilai $T$ tertentu, nilai radiasi hanya merupakan fungsi panjang gelombang $\lambda$, sehingga dapat dibuat grafik dari Persamaan (1) seperti yang diperlihatkan pada Gambar 3.

Pada Gambar 3 diperlihatkan hubungan antara radiasi terhadap panjang gelombang untuk beberapa nilai suhu. Tiap nilai suhu memiliki sebuah kurva yang merupakan fungsi panjang gelombang, sebagai contoh blackbody dengan suhu $1300 \mathrm{~K}$ atau sekitar $1027^{\circ} \mathrm{C}$ kurvanya meliputi daerah ultra violet, sinar tampak dan infrared, dengan nilai radiasi maksimumnya pada sekitar panjang gelombang $2 \mu \mathrm{m}$. Sedangkan pada suhu 2800 $\mathrm{K}$ nilai radiasi maksimumnya berada pada sekitar panjang gelombang $1 \mu \mathrm{m}$.

Pada Gambar 3 terlihat bahwa semakin besar nilai suhunya maka panjang gelombang untuk radiasi maksimum bergeser menuju panjang gelombang yang lebih pendek.Sebagai penyerap panas sempurna (perfect absorber) dan pemancar panas yang sempurna (perfect emitter), blackbody merupakan radiator panas ideal.Tak ada permukaan yang memiliki sifat yang persis sama dengan blackbody.

Namun demikian blackbody dapat didekati dengan suatu rongga kedap cahaya (opaque enclosure) yang seluruh permukaan 
dalamnya memiliki suhu yang sama (isothermal surface). Skema rongga tersebut diperlihatkan pada Gambar 5. Blackbody praktis merupakan pendekatan dari blackbody ideal. Pendekatan ini mengacu pada dua sifat utama dari blackbody ideal, yaitu perfect absorber dan perfect emmiter.

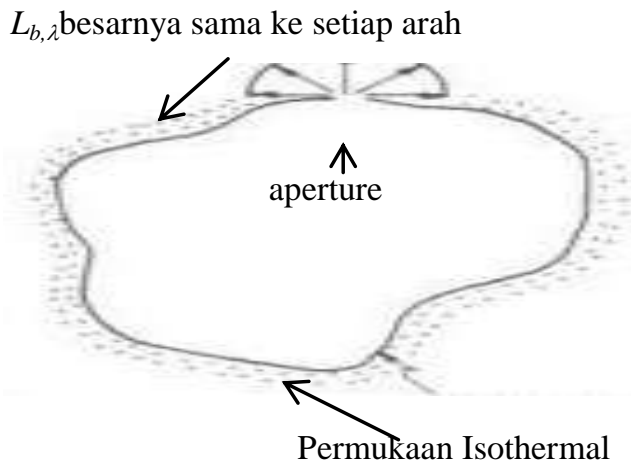

\section{Gambar 4. Rongga pendekatan blackbody}

Agar dapat memenuhi kedua sifat utama tersebut maka bentuk blackbody praktis mengikuti pola permukaan seperti yang ditunjukkan pada Gambar 4. Agar memenuhi pola tersebut maka blackbody praktis berbentuk cavity. Selain itu supaya emisivitasnya tidak bergantung pada panjang gelombang maka sebagai bahan cavity yang dipilih adalah logam graybody seperti graphite atau logam yang telah dioksidasi.

Disamping itu, agar radiasi yang masuk ke dalam rongga tidak ada yang memantul keluar rongga, sehingga rongga dapat berfungsi sebagai perfect absorber, maka dimensi rongga dibuat sedemikian rupa sehingga memiliki jari-jari bukaan $r$ yang relatif kecil bila dibandingkan dengan kedalaman rongga R. Lihat Gambar 5.

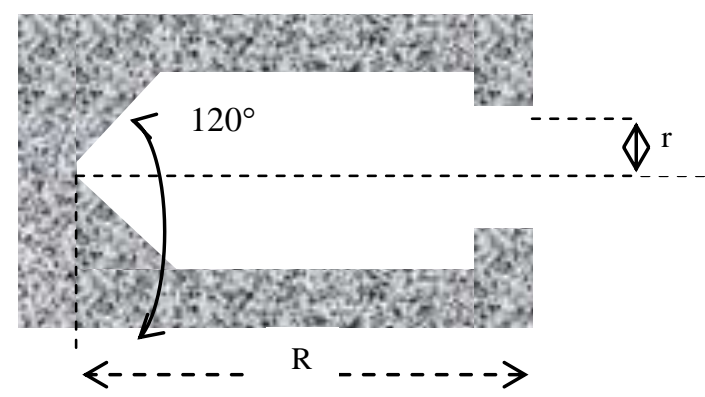

\section{Gambar 5. Skema blackbody cavity}

Sebagai contoh untuk memperoleh emisivitas sebesar 0.998 dengan emisivitas bahan 0.9 maka besarnya perbandingan antara $r$ dan $R$ adalah 1 berbanding 8. Bila nilai perbandingan tersebut dibuat semakin besar dan permukaan belakang rongga (bottom surface) dibuat membentuk sudut $120^{\circ}$ maka proses refleksi yang terjadi di dalam rongga dapat mempersulit keluarnya radiasi yang telah masuk untuk keluar lagi melalui lubang rongga. Dengan demikian maka nilai emisivitasnya semakin membesar dan mendekati 1 sehingga semakin mendekati emisivitas blackbody ideal.

Tungku akan memanaskan blackbody cavity sehingga rongga tersebut memiliki suhu tertentu dan kemudian dipancarkannya sebagai radiasi panas melalui bukaan rongga. Disamping itu, agar radiasi panas yang dipancarkannya tersebut mendekati sifat pancaran blackbody teoritis, sehingga rongga dapat berfungsi sebagai perfect emmiter, maka suhu tungku harus merata sedemikian rupa sehingga dapat membuat suhu rongga merata pula pada seluruh permukaannya.

Secara sederhana emisivitas blackbody cavity dapat didekati berdasarkan pada Persamaan ${ }^{[3]}$ :

$$
\begin{aligned}
& \varepsilon=1-\left(1-\varepsilon_{g}\right) \frac{\mathrm{r}^{2}}{\mathrm{R}^{2}} \\
& \text { dengan : } \\
& \quad \varepsilon=\text { emisivitas blackbody cavity } \\
& \varepsilon_{\mathrm{s}}=\text { emisivitas bahan }
\end{aligned}
$$

Persamaan (2) hanya memperhitungkan faktor dimensi rongga dan emisivitas bahan, sedangkan beberapa faktor lain belum diperhitungkan, diantaranya faktor refleksi yang mungkin terjadi pada rongga dan faktor keseragaman suhu di sekeliling blackbody cavity. Salah satu contoh sederhana apabila kita menghitung emisivitas blackbody cavity yang terbuat dari bahan Inconel yang permukaannya dikasarkan dan dioksidasi, bila diameter bukaan $r=0,5 \mathrm{~cm}$, panjang $R=10$ $\mathrm{cm}$ dan emisivitas bahan $\varepsilon_{\mathrm{s}}=0,9$, maka nilai emisivitas blackbody cavity Inconel tersebut adalah: $\varepsilon=1-0,1 \times 0,5^{2} / 10^{2}=0,99975$. Dari nilai emisivitas yang mendekati nilai 1 ini terlihat bahwa blackbody cavity mendekati sifat blackbody ideal. Perhitungan emisivitas yang lebih lengkap adalah dengan metode Integrative-Cavity dimana factor-faktor lain seperti refleksi telah diperhitungkan.

Salah satu cara lain yang lebih kompleks yang banyak digunakan untuk menghitung nilai emisivitas adalah dengan metode Integrative-Cavity, metode ini menggambarkan pertukaran radiasi antara permukaan secara analitis ${ }^{[5,6]}$. Metode Integrative-Cavity melakukan pendekatan perhitungan nilai emisivitas local $\varepsilon_{\mathrm{x}}$ pada segmen tertentu di posisi $\mathrm{x}$ dan suhu $T$ dengan menjumlahkan seluruh komponen 
radiasi $\mathrm{n}$ segmen yang mencapainya. Untuk kondisi non-isothermal $\left(T(x) \neq T_{0}\right)$ dan pantulan menyebar (diffuse reflection) $(\varepsilon \neq$ $f(\alpha)$ ), nilai emisivitas didekati dengan persamaan:

$\varepsilon_{x}\left(T, T_{0}\right)=\varepsilon_{x}(T) \frac{L_{x}(T)}{L\left(T_{0}\right)}+\left(1-\varepsilon_{x}(T)\right) \cdot \sum_{i=1}^{n} \varepsilon_{i, j}, F_{i, j}$

Dimana :

$\varepsilon_{x}\left(T, T_{0}\right)=$ emisivitas di posisi $\mathrm{x}$ dan suhu $T$ dengan pengaruh $T_{0}$ diperhitungkan

$\varepsilon_{x}(T)=$ emisivitas di posisi $x$

$L_{x}(T)=$ nilai radiasi di posisi $x$ pada suhu $T$

$L\left(T_{0}\right)=$ nilai radiasi pada suhu $T_{0}$

$\varepsilon_{i, j}=$ nilai emisivitas pada segmen $i, j$

$F_{i, j}=$ nilai form factor pada segmen $i, j$

Dalam kondisi isothermalradiasi lokal nilainya tetap di seluruh permukaan cavity $L\left(T_{0}\right)=L_{i, j}=L_{x}$ dan persamaan menjadi lebih sederhana yaitu :

$\varepsilon_{x}=\varepsilon_{x}+\left(1-\varepsilon_{x}\right) \cdot \sum_{i=1}^{n} \varepsilon_{i, j} \cdot F_{i, j}$

Blackbody cavity yang dibuat pada penelitian ini berupa cylindrical cone cavitydari bahan tembaga dengan conical aperture karena tipe inimemiliki akurasi yang lebih bagus bila dibandingkan dengan tipe lainnya.

\section{METODE PENELITIAN}

Penelitian ini dilakukan dari bulan Februari tahun 2019 di Laboratorium SNSU Badan Standardisasi Nasional Serpong. Pembuatan cavity blackbody ini diperlukan untuk system kalibrasi termometer telinga. Skema cavity blackbody yang dibuat berupa cylindrical cone cavity dengan conical aperture sesuai dengan desain dasar dari JIS T 42072005 tentang Ear thermometer.

Pada tulisan ini, dihitung dan disimulasikan nilai emisivitas spektral efektif dan gabungan dengan perangkat lunak perangkat lunak blackbody emissivity versi 1.2. Persamaan (3) digunakan untuk menghitung emisivitas pada kondisi nonisothermal dan persamaan (4) digunakan untuk menghitung emisivitas pada kondisi isothermal pada cavity blackbody yang telah dibuat. Emisivitas efektif yang dihitung adalah emisifitas efektif pada dasar cone cavity blackbody, sedangkan emisivitas gabungan dihitung dengan mensimulasikan blackbody cavity yang dibuat dengan termometer nonkontak dengan berbagai macam field of view.

\section{HASIL DAN PEMBAHASAN}

Desain blackbody cavity yang dapat dilihat digambar 6 dan hasil blackbody cavity yang dibuat dapat dilihat di Gambar 7.

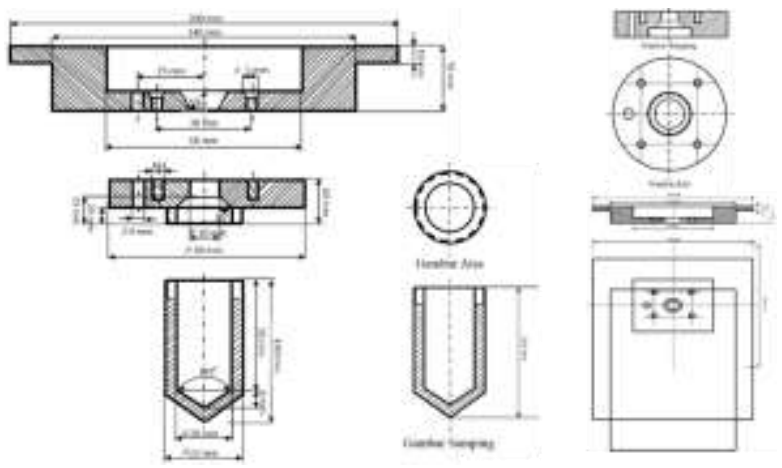

Gambar 6. Desain blackbody cavity

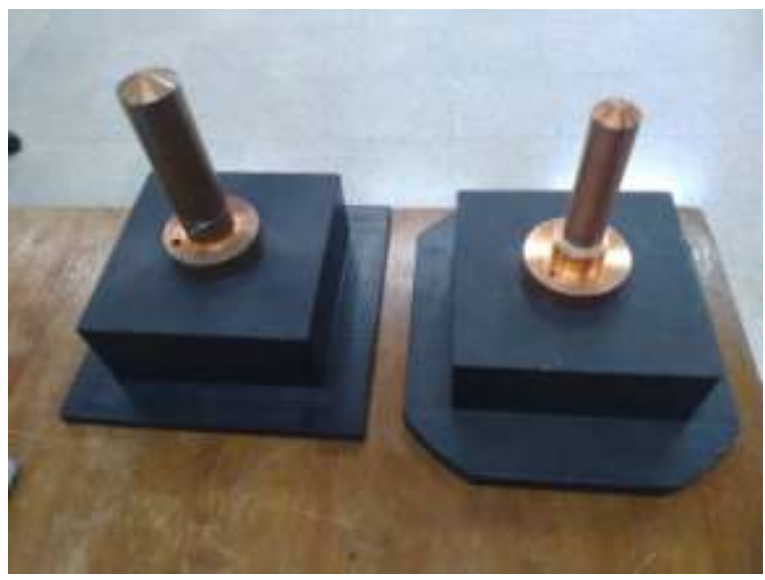

Gambar 7. Blackbody Cavity tembaga yang dibuat

Berdasarkansimulasi emisivitas saatisothermal, dinding cavity blackbody dianggap memiliki penyebaran suhu ideal yang merata, sehingga didapat hasil simulasi emisivitas sebagai berikut:

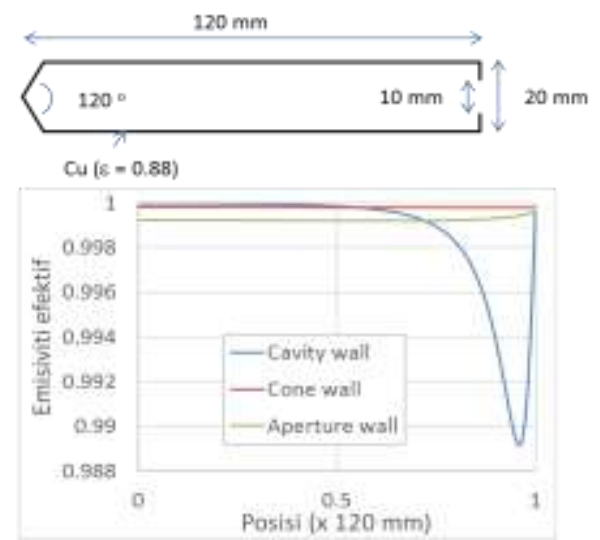

Gambar 8. Emisivitas Efektif Blackbody Cavity(isothermal) 


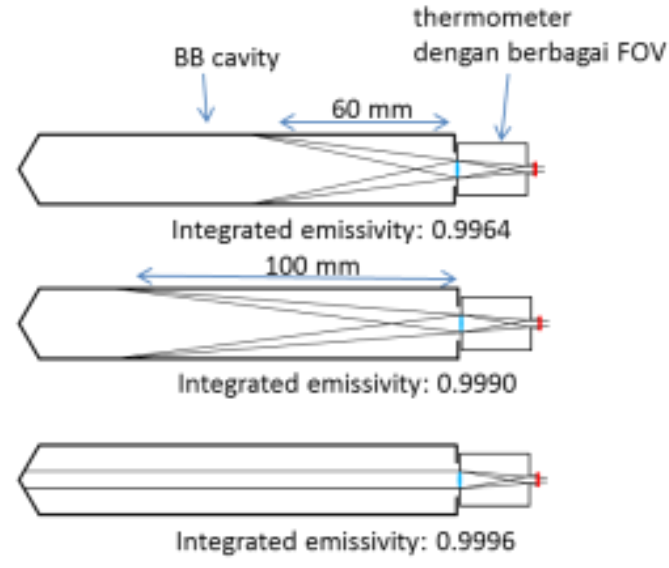

Gambar 9. Emisivitas Gabungan Blackbody Cavity (isothermal)

Pada kondisi ideal ini didapat emisivitas spektral efektif hingga $>0,999$ di titik dasar blackbody cavity dan emisivitas gabungan senantiasa $>0.99982$ untuk berbagai jenis termometer non-kontak dengan berbagai macam field of view.

Berdasarkan simulasi emisivitas saat non-isothermal, dinding cavity blackbody dianggap memiliki penyebaran suhu yang tidak merata, ketidakmerataan ini terutama dipengaruhi oleh bukaan blackbody yang terpengaruh oleh udara luar, yang berarti semakin mendekati bukaan blackbodymaka suhu dinding blackbody akan semakin berkurang bila dibandingkan dengan suhu pada dasar blackbody, sehingga didapat hasil simulasi emisivitas sebagai berikut:

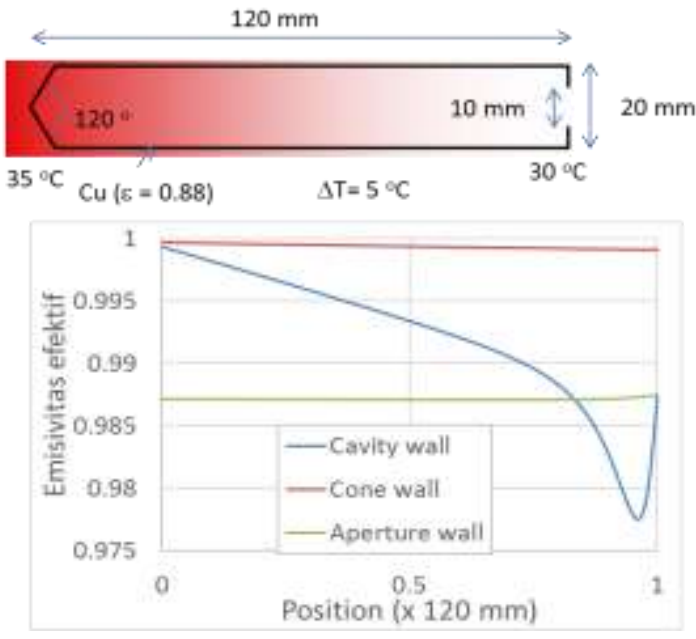

Gambar 10. Emisivitas Efektif Blackbody Cavity (non-isothermal)

Pada kondisi non-isothermal, didapat emisivitas spektral efektif hingga > 0,999 di titik dasar blackbody cavity dan dan emisivitas gabungan senantiasa $>0,9996$ untuk berbagai jenis termometer non-kontak dengan berbagai macam field of view.

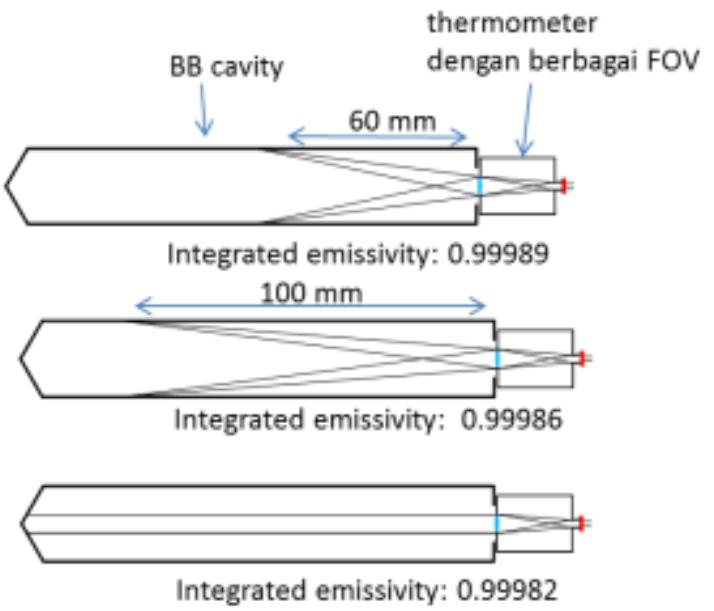

Gambar 11. Emisivitas Gabungan
Blackbody Cavity (isothermal)

\section{KESIMPULAN}

Dari penelitian telah dirancang blackbody cavity yang dibuat berupa cylindrical cone cavity dengan conical aperturepada saat isothermal dapat memiliki emisivitas efektif hingga mencapat> 0,999 di titik tengah dasar cavitydan emisivitas gabungan senantiasa > 0.99982 untuk berbagai jenis termometer nonkontak dengan berbagai macam field of view.Pada kondisi non-isothermal, didapat emisivitas spektral efektif hingga $>0,999$ di titik dasar blackbody cavity dan dan emisivitas gabungan senantiasa > 0,9996 untuk berbagai jenis termometer non-kontak dengan berbagai macam field of view.

\section{UCAPAN TERIMAKASIH}

Ucapan terima kasih penulis ucapkan kepada pemberi dana penelitian yaitu Program Insentif Riset Sistem Inovasi Nasional (INSINAS) Pendanaan Tahun 2019 dari Kementerian Riset, Teknologidan Pendidikan Tinggi dan kepada pimpinan Badan Standardisasi Nasional dan jajaran manajemen yang telah menyediakan sarana dan prasarana untuk melaksanakan penelitian ini serta semua anggota penelitian dan pihak lain yang telah membantu menyelesaikan penelitian ini.

\section{DAFTAR PUSTAKA}

Larassati, D., Rifai, I. A., dan Zaid, G. (2015) Analisa perhitungan nilai emisivitas spektral efektif cavityblackbody untuk kalibrasi ear thermometer, PPI KIM 
LIPI.

Body temperature norms, Retrieved

September 14,

2019 https://medlineplus.gov/ency/article/001 982.htm

DeWitt, D.P. dan Gene D.Nutter. (1988). Theory and practice of radiation thermometers. Singapore: John Wiley.

Zhang, Z., Tsai, B.and Machin, G.(2009). Radiometric Temperature Measurement (I. Fundamental). Hal. 282283,Academic Press

Nicholas, J.V. dan D.R. White. (2005). Traceable Temperature, Second Edition. Singapore: John Wiley.. Amsterdam: Academic Press.

Sakuma, F. and Ma, L. (2004). "Cavity emissivity of a fixed-point blackbody," in Tempmeko 2004, D.; Zvizdic, Ed., Zagreb, FSB.

Yoon,H. Gibson,C. and Johnson, B, (2001). On the determination of emissivity of the variable temperature blackbody used in the dissemination of the us national scale of radiance temperature," in Temomeko 2001, p.221.

Ishii, J., Fukuzaki,T., McEvoy, H.C., Simpson, R., Hartmann, J., andHollandt, J. (2004). "A Comparison of the blackbody cavities for infrared ear thermometers of NMIJ, NPL and PTB", Proc. of TEMPMEKO'04,

I. Pusnik, E. van der Ham, J. Drnovsek, (2004). "Comparison of blackbody cavities for calibration of infra-red ear thermometers", Proc. Of TEMPMEKO'04.

J. Ishii, T. Fukuzaki, T. Kojima, A. Ono, (2001). "Calibration of infrared ear thermometers",

Proc. TEMPMEKO'01,

JIS T 4207: 2005, (2005). Infrared ear thermometers, Japan Measuring Instruments Federation, 
